\title{
Problémový žák a problémové chování z pohledu školních metodiček prevence
}

The Problematic Pupil and Problematic Behaviour from the Perspective of School Prevention Methodology Specialists

\section{Nikola Petrek, Veronika Pavlas Martanová}

Katedra psychologie, Pedagogická fakulta, Univerzita

Karlova v Praze

Abstrakt Výzkum se věnuje oblasti problémového chování žáka na základní škole. Cílem bylo zmapovat tuto problematiku z pohledu samotných učitelek, konkrétně školních metodiček prevence. Pozornost byla věnována především konkrétním zkušenostem pedagogů s žáky s problémovým chováním. Kvalitativní data byla získána prostřednictvím semistrukturovaných rozhovorů s pěti školními metodiky prevence a pro zpracování interview byla použita metoda Zakotvené teorie. Výzkum ukázal, že dle názoru vyučujících, se na vzniku problémového chování podílí několik faktorů. Jedná se především o negativní rodinné působení, faktory, na nichž se podílí škola a také vstup žáků do období dospívání. Školní metodičky prevence se nejčastěji ve své praxi setkávají se vzájemným napadáním mezi žáky, nerespektem vůči dospělým osobám (především vůči pedagogům), zapomínáním a záškoláctvím. $Z$ výsledků výzkumu také vyplynulo, že přítomnost problémového žáka má zásadní vliv na zbytek třídy, a především samotného pedagoga.

Klíčová slova problémový žák, problémové chování, školní poradenství, školní metodik prevence.

Abstract This article presents the results of research which deals with problematic behavior of elementary school pupils. The risk or problem behavior of pupils is a relatively 
broadly-researched phenomenon, yet there is still inconsistency in the definition of its basic concepts. Problem behavior is the kind of behavior described as unresponsive, aggressive, social, dissocial, antisocial, socially pathological, addictive, maladaptive or non-adaptive.

The aim of the research was to map the issue from the point of view of the teachers themselves, specifically the school prevention methodology specialists. Attention was paid to the teachers' actual experience with pupils displaying problematic behavior. Wragg (1984) notes that problematic behavior at school is mostly present in the form of minor problems, which, however, can be very stressful for educators. These include, for example, running around the school desk, talking without permission, creating classroom noise, or refusing to work. Such behavior is often more common than physical violence. Fontana (2003) mentions the importance of the teacher's subjective perception when defining problematic pupils; what one teacher tolerates may be considered to be a gross violation of rules by another. In the field of problem behaviour, it is always up to the observer.

The qualitative data were obtained through semi-structured interviews with five school prevention methodology specialists, and the Grounded Theory method was used to process the data. The findings show that, in the teachers' perspective, several factors are involved in problem behavior. They are, particularly, negative family influence, school-related factors, and also the pupil's transition to adolescence. Most frequently encountered forms of problem behaviour included violence amongst the pupils, disrespect towards adults (mainly teachers), forgetfulness and truancy. The results also showed that the problematic pupil has a major impact on the rest of the class and, above all, on the teachers themselves.

Keywords problematic pupil, problem behavior, school counselling, school prevention methodology specialist. 


\section{Problém}

Problémové chování na základní škole vymezuje Fontana (2003) jako chování, které je nějakým způsobem nepřijatelné pro vyučujícího. Byt’ se tato definice jeví jako velmi zjednodušená, upozorňuje na to, že problémové chování je problémovým $z$ toho důvodu, že se takto jeví konkrétnímu vyučujícímu. Vojtová (2004) taktéž uvádí, že literatura za problémového žáka vnímá někoho, kdo svým chováním nebo výkony nesplňuje očekávání pedagoga a představuje pro něj jakousi přítěž, jelikož vyžaduje speciální pozornost. Vágnerová (2011) zmiňuje, že žák s problémovým chováním má nejčastěji obtíže v oblasti výkonu a školního prospěchu. Dále v oblasti chování, kdy svým chováním vybočuje nad ostatní žáky, narušuje normy ve škole či je jinak nápadný. A v neposlední řadě také v oblasti citového prožívání. To se týká především bázlivých či nápadně úzkostných žáků. Takoví žáci však mnohdy unikají pozornosti vyučujících, jelikož jsou spíše svými projevy nenápadní a proto bývají často považovány za bezproblémové (Vašutová, 2005).

\section{Příčiny a projevy problémového chování}

Abychom mohli pochopit př̌́činy problémového chování žáků na základní škole, je nezbytně nutné se zamyslet nad zázemím takového jedince (Fontana, 2003). Žáci mnohdy svým chování vyžadují pouze to, aby jim někdo věnoval svou pozornost, které se jim od nejbližších členů rodiny nemusí dostávat. Některé chování však může být spjato se sociálním nebo ekonomickým kontextem rodiny (Auger \& Boucharlat, 2005). Rozvody či rozchody rodičů, nově uzavřené sňatky, prozrazení adopce či alkoholismus v rodině se na chování dítěte taktéž jistě podepisují (Vašutová, 2005). Dítě se pak svým rodičům odcizuje, vzdoruje jim nebo si dělá, co chce. Auger a Boucharlat (2005) dále uvádějí, že mnoho rodičů dává $v$ dnešní době přednost místo výchovného působení na dítě spíše citovým vztahům. Rodiče se záměrně vyhýbají příkazům a zákazům, snižují nároky kladené na děti a konfliktům se snaží předcházet. Ty je poté odmítají respektovat a odmítají se přizpůsobit nárokům a požadavkům pedagogů. Jedním $z$ nezbytných předpokladů toho, aby práce vyučujícího s žákem byla efektivní, je znalost žáka a jeho rodinného zázemí (Vojtová, 2004). Spolupráci rodiny a školy však mnohdy znesnadňují právě rodiče svým negativním postojem a agresivním chováním vůči pedagogům (Cole, Visser, \& Upton, 1998). Rabušicová a Pol (1996) ve svém výzkumu zjistili, že mezi rodinou a školou stále ještě existuje komunikační bariéra, která je způsobena nedostatkem respektu a důvěry. Pro zlepšení komunikace je nutné, aby se netýkala vždy jen negativních věcí a nedostatků žáka. Naopak by škola měla komunikovat s rodinou i v případě malých pokroků či zlepšení.

Další příčinou problémového chování žáků mohou být změny vyplývající z období dospívání. Žáci se musí adaptovat na druhý stupeň základní školy, mohou se potýkat s krizí osobnosti, která je spojena s transformací dítěte na dospělého, což bývá spojeno s konflikty s autoritami obecně. Nejvíc se však tyto konflikty objevují ve vztahu k pedagogům či rodičům (Vašutová, 2005).

Žáci jsou ve škole mnohdy nespokojení s tím, že je vyučující neberou př́liš vážně a nemají právo vyjadřovat se $\mathrm{k}$ věcem, které považují za důležité (Auger $\&$ Boucharlat, 
2005). Stěžují si na učitele, kteří jimi pohrdají, ponižují je, nejeví o ně zájem nebo na ty, kteří si myslí, že mají vždycky pravdu. Haribot (1980, in Auger \& Bourcharlat, 2005) uvádí, že ve chvíli, kdy je žák ve škole nespokojený a situaci vnímá subjektivně jako ohrožující, může reagovat třemi různými způsoby - útěkem, útokem či podřízením. Mluvení při vyučování, nezájem o dění ve tř̌idě nebo probírané učivo, pasivita, apatie, nevolnosti a úzkosti jsou projevy útěku, stejně jako např́klad záškoláctví, které ve škole patří mezi velmi závažné problémy (Čáp \& Dosoudil, 2013). Reakci útokem volí žáci ve chvíli, kdy na ně pedagog klade předem nedohodnuté požadavky, je nespravedlivý či vystupuje př́liš autoritativně nebo jim nenaslouchá a pohrdá jimi. Naopak podřízením se, se žák stává závislý na školních normách a to i na úkor vlastního osobnostního rozvoje.

V neposlední řadě má na chování žáka vliv také přístup pedagoga.Vágnerová (2001) uvádí, že žák s problémovým chováním od vyučujícího vyžaduje odlišný př́istup. Zároveň mu také přináší méně uspokojení, protože výsledek neodpovídá jeho vloženému úsilí. Role takového žáka není vymezena pouze jeho projevy, ale také jejich interpretací ze strany učitele. Pokud je vina za problémové chování přičítána jiné osobě či například nemoci, bývá dítě mnohem více tolerováno. Přiřčení role problémového žáka je pak výsledkem interakce učitele a žáka a tento stereotyp se pak velmi snadno předává mezi dalšími pedagogy. To je však logické, nebot' pokud mu tuto roli přisoudí např́klad učitel s dlouholetou praxí, nemají důvod kolegové jeho názor odmítat.

Wragg (1984) ve svém výzkumu zmiňuje, že většina problémového chování ve škole se projevuje v podobě nepatrných problémů. Právě ty však mohou být pro pedagogy velmi stresující. Jedná se například o odbíhání z lavice, mluvení bez dovolení, hluk ve třídě nebo odmítání pracovat na zadaném úkolu. Takové chování pak bývá mnohem častější než fyzické násilí nebo urážení vyučujících. Fontana (2003) pak zmiňuje individualitu pedagogů při definování problémových žáků. To, co jeden učitel toleruje, může druhý považovat za hrubé porušování pravidel. V oblasti problémového chování tedy vždy záleží především na pozorovateli.

\section{Metodologie}

\section{Výzkumné cíle}

Cílem výzkumu bylo zmapovat téma problémový žák a problémové chování na základní škole tak, jak ho vnímají samotní vyučující, resp. přímo školní metodičky prevence. Výzkum se zabýval především tím, kdo je pro školní metodičky prevence problémový žák, jak ho vnímají a čím se dle nich vyznačuje. Pozornost byla věnována zejména konkrétním zkušenostem respondentů s žáky s problémovým chováním.

Na základě výše zmíněných cílů byly definovány celkem čtyři výzkumné otázky:

1. Kdo je, dle školních metodiček prevence, problémový žák a jak se projevuje?

2. Co školní metodičky prevence vnímají jako největší problémovost?

3. S jakým problémovým chováním se školní metodičky prevence setkávají ve své praxi nejčastěji?

4. Jakým způsobem ovlivňuje přítomnost problémového žáka ve tř̌́dě výuku? 


\section{Výzkumný soubor}

Výzkumný soubor tvořily pedagožky, které na základní škole zároveň zastávají funkci školního metodika prevence. Takový vyučující by se měl mimo jiné zaměřovat na primární prevenci rizikového chování. Mezi takové chování řadíme např́klad agresi, šikanu, kyberšikanu, rasismus a xenofobii, záškoláctví, závislostní chování, užívání všech návykových látek, rizikové sporty, poruchy př́ijmu potravy, negativní působení sekt nebo také sexuální rizikové chování (Knotová et al., 2014). Mezi činnosti školního metodika prevence by tak mělo dle vyhlášky MŠMT 72/2005 Sb., ve znění pozdějších předpisů, o poskytování poradenských služeb ve školách a školských zařízeních, mimo jiné patří vyhledávání a orientační šetření žáků s rizikem nebo projevy sociálně patologického chování', včetně poskytování poradenských služeb těmto žákům a jejich zákonným zástupcům a v neposlední řadě také spolupráce s třídními učiteli při sledování varovných signálů. Školní metodik prevence na základní škole bývá tedy jakousi styčnou osobou pro ostatní vyučující. Právě z těchto důvodů a výše zmíněným kompetencím školního metodika prevence jsme se rozhodli věnovat se oblasti žáka s problémovým chováním právě z pohledu vyučujících, kteří se s tímto fenoménem potýkají při své práci nejčastěji.

Výzkumu se účastnilo pět školních metodiček prevence. Nejstarším pedagožkám bylo 51 let, nejmladší pak 44 let. Až na jednu vyučující, která působila jako učitelka pouze jeden rok (předtím vykonávala funkci vychovatelky), se všechny ženy pohybovaly ve školství jako vyučující minimálně dvacet let. Výběr zkoumaného vzorku probíhal metodou záměrného výběru, kde kritériem výběru bylo, aby pedagog zastával funkci školního metodika prevence bez ohledu na to, zdali má v této oblasti ukončené specializační studium pro školní metodiky prevence či jak dlouho tuto funkci na škole zastává.

\section{Metody získávání a analýzy dat}

Výzkumnou metodou bylo použito semistrukturované interview. Jednalo se o schéma sedmnácti předem připravených otázek, které byly rozděleny do celkem dvou větších celků. První okruh byl zaměřen na funkci školního metodika prevence, oblast jeho působnosti a náplň práce. Druhý okruh se poté věnoval samotné oblasti problémového chování. Další doplňující otázky pak byly respondentkám pokládány dle témat, která se vynořila v rámci individuálních rozhovorů. Interview trvala v rozmezí od 18 do 54 minut, vždy záleželo na míře sdílnosti jednotlivých pedagožek a ochotě o daném tématu hovořit.

Výzkum vycházel ze Zakotvené teorie (Strauss \& Corbin, 1994), která je v českém prostředí poměrně hojně užívanou metodou analýzy kvalitativních dat. Tento postup zahrnuje otevřené a selektivní kódování. Přináší důkladné uspořádání a popis dat a umožňuje také interpretovat nejrůznější aspekty výzkumného tématu. Tématem se pak rozumí vzorec objevený v datech, který je popisuje, organizuje a interpretuje (Boyatzis, 1998). Ve výběru a prezentaci témat hraje aktivní roli výzkumník, jenž po celu dobu kódování dat i extrakce témat stále vstupuje do dialogu s výzkumným materiálem a reflektuje analyický

Sociálně patologické jevy jsou takové jevy, jež se negativně odchylují od norem a hodnot uznávaných ve společnosti (napři. prositutce, xenofobie, rasismus a další). (Bělík, Hoferková, Kraus a kol., 2017). 
proces jako takový. V rámci analýzy rozhovorů bylo dodrženo následujícího doporučeného postupu (Strauss \& Corbin, 1999): otevřené kódování získaných rozhovorů, roztřídění textu na významové jednotky a přidělení patřičných kódů a v neposlední řadě také kategorizace, která spočívala v seskupování kódů na základě podobnosti. $\mathrm{V}$ analýze jsme pracovali s tématy explicitně vyjádřenými. Vzhledem ke kvalitativní povaze dat a též k povaze analýzy poskytují jednotlivá témata rozsáhlý objem citací, který v textu využíváme pro lepší přiblížení problému. Citace $\mathrm{z}$ rozhovorů jsou v textu psány kurzívou. Pokud uvedené citace obsahovaly jména, nahradili jsme tato jména smyšlenými. $\mathrm{V}$ tomto procesu pak vznikly čtyři kategorie popsané v další části textu, na nichž se pokoušíme popsat celý mechanismus z pohledu ŠMP (definici problémového chování, jeho př́činy a důsledky a zejména „brzdící“/ protektivní faktory jeho rozvoje).

\section{Výsledky}

V dalším textu představíme výsledky tak, jak naznačuje následující schéma.

\section{Schéma 1}

Výsledky výzkumu

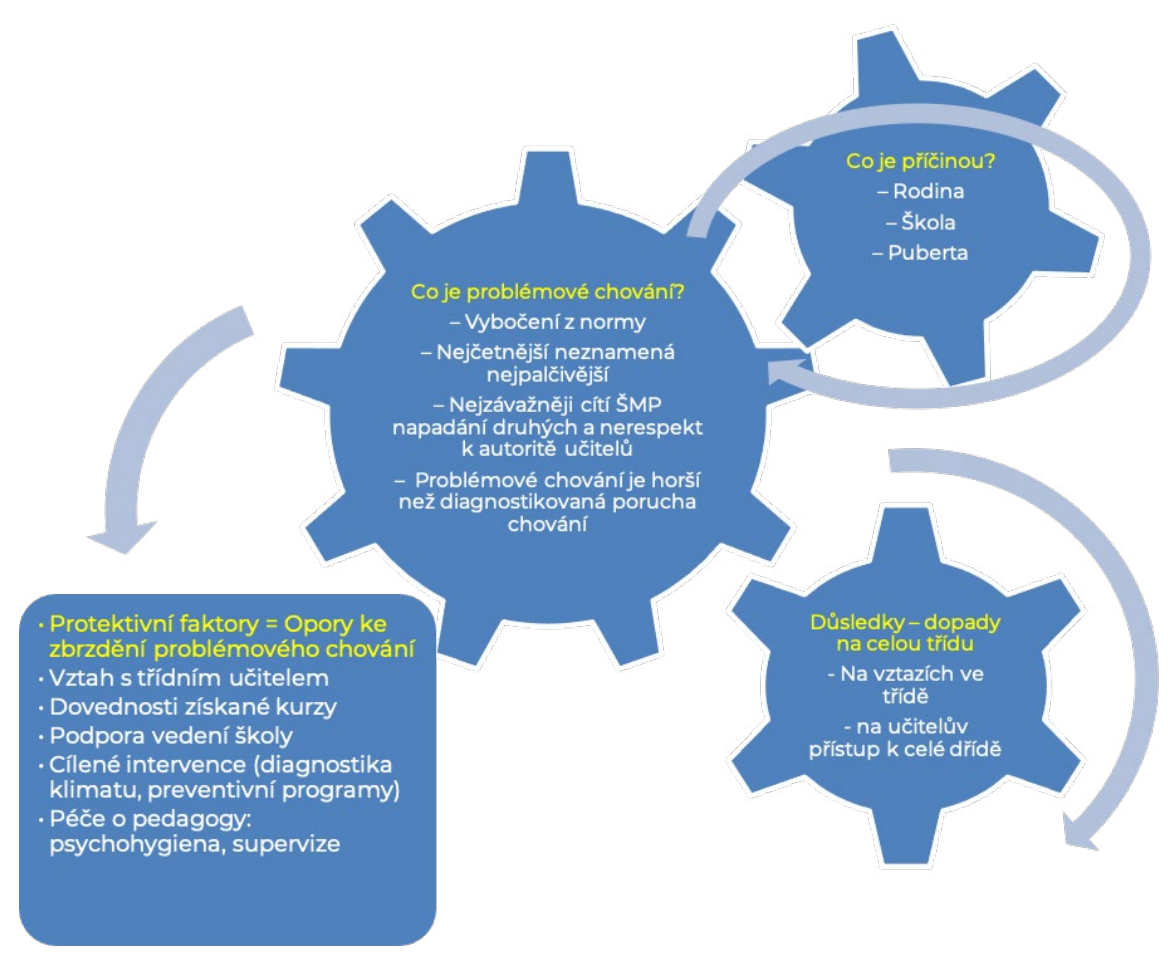

\section{Co je problémové chování a kdo je problémový žák}

Ze získaných dat vyplynulo, že školní metodičky prevence vnímají problémového žáka jako někoho, kdo se chová nějakým způsobem nestandardně, jinak než ostatní a svým chováním narušuje vyučování dalším žákům včetně pedagoga samotného. „Když se řekne 
problematický žák, tak je to nějakej žák, kterej se nějak jakoby vymyká z toho kolektivu. Kterej se chová nestandardně...“ Takový žák má také obtíže v mezilidských vztazích, kdy na spolužáky i pedagogy bývá agresivní, hrubý či je jinak napadá. „Agresivni, nerespektuje učitele, nadává jim vulgárně v podstatě. Takže žádnej respekt $k$ učiteli $k$ tomu..." Někdy jeho chování sklouzne až $\mathrm{k}$ šikaně. Jedná se tedy obecně o žáka, který jakýmkoli způsobem ubližuje ostatním lidem kolem sebe. Pedagogové vnímají, že cílem takového chování je získat především pozornost nebo si tím žáci kompenzují nedostatek vědomostí. Žák s problémovým chováním má také často zkušenosti s různými návykovými látkami (at̉ už se jedná o alkohol, cigarety či marihuanu). Jeho chování však může vycházet také z jeho diagnózy či situace v rodině.

Školní metodičky prevence vnímají jako největší problémovost u žáků základních škol vzájemné ubližování si. „Já teda musím říct, já teda co mně úplně nejvíc vadí ze všeho je to, když fakt někdo záměrně někomu ubližuje. A ještě když si jako vybere slabšího, tak to je pro mě jakoby nejhorši věc, která je mezi těma dětma jo. To, že nenosí věci, to že teda jako vykř̌ikuje a vyrušuje jo, podle mě todle všechno se dá zvládnout nějakým jako fíglem jo. Na každý dítě funguje něco jinýho a podle mě se to dá zvládnout. (...) Je to takový ubližování, že to dítě pak nechce chodit do školy. Že to vyplyne až do tohohle toho, že to ditě se pak boji chodit do školy. To mně prijjde jako úplně nejhorši a nejproblémovějši co je v tý škole."

Dále také nerespektování dospělých osob, přičemž žáci věšinou nemají motivaci cokoli na svém chování měnit.

Co se týká chování žáků v oblasti školních povinnosti, nejčastěji se pedagogové ve své praxi setkávají se záškoláctvím, které mnohdy kryjí, tedy různě omlouvají samotní rodiče těchto žáků. Dále se zapomínáním nebo celkově takzvanou špatnou pracovní morálkou. Takové chování ale respondentky považují za natolik běžné, že ho vlastně ani nepovažují za problémové. „Řešíme hodně asi zapominání, špatnou pracovní morálku a drzost na učitele. Ale to je tak běžný, že to snad bych ani neřekla, že to je problém.“ „Jako já vám to řeknu takhle, jako pro mě po těch triceti letech praxe už nějaký zapominání je naprosto jako mimo jo. Že bych ho brala jako problémovýho, prostě některý dítě takový je a já už se tím vůbec nezabejvám, jako fakt ne.“

V oblasti týkající se chování směrem ke spolužákůma a učitelům se vyučující setkávají nejčastěji se vzájemném nadáváním si na sociálních sítích. Žáci se tam vzájemně napadají nebo sdílejí nelichotivé fotografie svých spolužáků pro pobavení dalších lidí. Obecně se pak jedná o vulgaritu ke spolužákům i pedagogům, která je spjatá s výše popsaným nerespektem $\mathrm{k}$ autoritě.

Školní metodičky prevence jsou přesvědčeny, že u žáků s poruchami chování by se měl brát na jejich diagnózu větší ohled. „No tak ty poruchy, že jo, tak tam je to vrozený, tam relativně se hodně těžko něco mění, tam může se člověk pomáhat mu zklidňovat nebo učit sebeovládání, ale je to... je to těžší. A u těch problémových žáků, tam je to o těch rodičích si myslím hodně o výchově, o prostředí a o tom, jak se $k$ nim bude přistupovat i tady, že jo." Jejich chování je závažnějšího charakteru a má tak větší dopad na zbytek kolektivu ve třídě. Pokud se v jejich třídě objeví žák s diagnózou porucha chování, kontaktovaly by respondentky nějaká další pracoviště, od kterých by očekávaly, že škole pomůžou. Naopak žáka s problémovým chováním, by škola měla zvládnout sama ve spolupráci s rodiči. 


\section{Co je příčinou problémového chování}

Negativní rodinné působení

Nejčastějším důvodem problémového chování žáka, je dle respondentek, způsob výchovy rodičů, kteří se o takového žáka často nestarají, s výchovou na něj nestačí či na něj nejsou dostatečně přísní a důslední. „Jako neni to, že jo, nebývá to třeba problémová rodina jako $v$ tom smyslu, že si představime, že tatínek pije nebo tam vůbec nefunguje a tak. Ale ve chvíli, kdy vlastně je tam trošičku nějaký nesoulad ve výchově nebo prostě se něco v tý rodině děje, tak vždycky se to projeví na chování žáka. A to už se pak může stát, i že to není problém, do té doby to není problémový žák, vlastně ve chvíli, kdy se něco v té rodině děje, tak na tom dítěti se to pozná." Doma si pak s dítětem mnohdy sami neví rady. „Ale u některých dětí nebo u většiny těch problémových chování, tak většinou to, že tam jsou potiže doma a od toho se to všechno odvijí." Dalším faktorem bývá, že rodiče svému dítěti bezmezně věří a přehnaně jim naslouchají. Ve chvíli, kdy rodiče se školou spolupracují a slepě nevěří svému dítěti vše, co řekne, je velká šance dítě „narovnat“. Školní metodičky prevence také uváděly, že se často setkávají u žáků s problémovým chováním s nespolupracujícími rodiči, kteří svým dětem například kryjí absenci ve škole. Rodiče problém mnohdy popírají, dělají, že neexistuje či svalují vinu výhradně na školu.

Za problémovým chováním ale také může stát aktuálně probíhající rozvod rodičů, či sociální problémy v rodině (např. žák nechodí do školy, protože doma hlídá mladší sourozence ve chvíli, kdy je matka samoživitelka v práci).

Škola a postoj pedagogů

Některé respondentky také přiznaly, že na žákovo problémové chování může mít vliv i škola nebo postoj vyučujících $\mathrm{k}$ těmto žákům. Jako rizikové vnímají časté strǐ́dání učitelů ve třídě. Za další negativní faktor považují školní metodičky prevence tendence jiných pedagogů problémové chování bagatelizovat, at’ už z důvodu neochoty takové chování řešit či z důvodu, že takovému chování nepřikládají velký význam. „A ještě kdyžjá pak třeba na něco přijdu, tak voni to jako tak jako bagatelizujou a ř́kaj, vždyt'on si o to ř́ká sám jo.“

Dále $z$ výsledku výzkumu vyplynulo, že se ve školách mnohdy objevují obtíže s komunikací jak ze směru od třídních učitelů ke školním metodikům prevence, tak $\mathrm{v}$ rámci samotného školského poradenského zařízení. Vyučující často neinformují školní metodiky prevence o problémech, a ti poté nemají dostatek informací a nemohou tudíž včas zakročit.

\section{Puberta}

Všechny oslovené pedagožky se shodly na tom, že na problémové chování u žáků má zásadní vliv jejich vstup do období puberty, jejímž vlivem se problémové chování mnohdy ještě více prohloubí či jinak zhorší. Téměř všechny respondentky vnímají jako nejproblémovější žáky na druhém stupni, konkrétně pak v sedmé třídě, především právě z důvodu období nástupu puberty. 


\section{Dưsledky problémového chování}

Výzkum ukázal, že přítomnost žáka s problémovým chováním má zásadní vliv jak na zbytek tř́idy, tak samotného pedagoga. „V prvni raděje to ruší, na druhou stranu vlastně on je obírá o ten čas, který bych mohla věnovat těm slabším, těm který mě potřebujou v tu danou chvíli.“ Projevuje se to především tím, že ubírá pozornost ostatním spolužákům a není tak možné se po celou dobu trvání vyučovací hodiny věnovat výuce. To klade další nároky především na vyučujícího. Některé třídy takového žáka přijmou a stane se součástí kolektivu, jiné se spojí proti němu a z kolektivu ho vyčlení. „Jsou třídy, který toho žáka vstřebají a tím, že prostě on ten žák jakoby na něj nereagujou, tak kolikrát jako to funguje. Stejně tak, jako když třída některá má žáka s nějakým handicapem, tak některá ho př́mo vyšikanuje, tak ho jakoby vyšoupne a některá ho př́jme úplně normálně. To opravdu závisí i na tom, v jakým tom kolektivu to dítě je. I podle mě stupeň toho jeho problému, jak se to rozvine."

Pakliže problémový žák spolužákům ubližuje, mnohdy se ostatní ve třídě snaží být spíše nenápadní, aby se sami nestali terčem jeho útoků.

Respondentky se shodovaly, že co do postoje pedagogů k problémovému chování či problémovému žákovi, vždy záleží na individualitě učitele. Každý pedagog má jinde hranice toho, co vlastně za problémové považuje a kam až nechá žáky při vyučování zajít. Za stěžejní ale považovaly to, o jaké problémové chování se jedná. Výše bylo zmíněno, že za nejvíce problémové vnímají vzájemné ubližování, naopak takové zapomínání v dnešní době za problém nepovažují, jelikož se s ním ve školách setkávají velmi často.

Co se týká vlivu na práci vyučujících ve třídě, školní metodičky prevence v rozhovorech uvedly, že do třídy, kde se objevuje jeden či více žáků s problémovým chování, vstupují raději s nižším očekáváním. „Jde tam s tím, že se mưže něco dít, je na to připravenej, takže užv tý př́pravě, když si člověk dělá, tak si tam ř́ká, no tohle asi nestihneme nebo užjde s tím radši očekáváním nižším. Když jde s vyšším očekáváním, tak pak má hodinu nabouranou, je nervózní učitel a objeví se to i do toho prostoru mezi dětma. Takže je to spíš o tom očekávání učitele, sčím tam půjde no a jak jde nastavený.“

Školní metodičky prevence volí různá řešení problémového chování, dle individuality vyučujícího a typu problémového chování. $V$ př́ípadě vyrušování při hodině, pro žáka připraví práci navíc, aby neměl možnost a čas rušit. (...) musím pořád mít dopredu připravenou nějakou činnost pro něj, a i když mám pro něj př̀ipravenou činnost, tak prostě kolikrát je to silnější než on. (...) Dále nechávají žáka samotného se zklidnit a nijak nezasahují. Některé volí strategii diskuze, dokud své povinnosti nesplní a jiné se ho snaží jinak pozitivně motivovat a oceňovat před ostatními spolužáky. $\mathrm{V}$ případě, že si s ním dlouhodobě nevědí rady, volají si na pomoc jiné instituce, např́klad pedagogicko-psychologickou poradnu či středisko výchovné péče. $V$ př́padně nutnosti pak školní metodičky prevence komunikují s OSPODEM.

\section{Protektivní faktory = opory ke zbrždění rozvoje problémového chování}

Vztah s třídním učitelem

Co se týká vztahu (třídního) učitele a žáků, zmiňovaly respondentky především jeho důležitost. Tř́da musí být vedená třídním učitelem dobře, a to se pak projeví také na chování 
jednotlivých žáků i celé skupiny. „Že jsou k tomu učiteli otevřenější, potom, že, když to takhle řknu, nechtěj tomu tř́dnímu učiteli udělat něco, co by ho pak mrzelo, co by udělalo i ten náhled na tu tř́du jinej. Takže snažej se fungovat jako dobře, protože to chtěj i pro toho svého tř́dního učitele, s kterým jsou za dobře a kteýho maj rádi, takže jako pak tam cejtěj i malinko zodpovědnost, že mu to nechtěj udělat nějaký ty průšvihy. “ Jedna z vyučujících uvedla, že velmi záleží na pedagogovi z prvního stupně, který danou třídu od počátku formuje. Dále pak na třídnických hodinách, které jsou jedním z preventivních faktorů při vzniku rizikového / problémového chování. Jiná respondentka zase zmínila důležitost určitých osobnostních charakteristik, které by měl mít každý pedagog, jelikož ovlivňují vztah mezi učitelem a žáky. Jedná se především o vrozený respekt a autoritu.

\section{Dovednosti získané kurzy}

Školní metodičky prevence se shodovaly v tom, že nepovažují za nutné, aby měl každý vyučující stejně obsáhlé vzdělání jako je Specializační studium pro školní metodiky prevence. Nějaké kurzy či semináře by však dle jejich názoru absolvovat měly, jelikož dovednosti nutné $\mathrm{k}$ dobrému vedení třídy a práce se skupinou se na pedagogických fakultách neučí. Obsahem těchto kurzů by pak mělo být především jak vést třídnické hodiny, které by neměly být pouze o technických záležitostech třídy, ale cílem by mělo být právě rozvíjení vztahu mezi učitelem a žáky a mezi žáky navzájem.

\section{Podpora vedení školy}

Dalším protektivním faktorem je dle školních metodiček prevence podpora ze strany vedení školy, která jim velmi pomáhá a oceňují ji. „Určitě potřebujou podporu. Je špatně, když ten učitel na to zůstane sám, takže ta podpora určitě. At̉ už ze strany vedení školy anebo metodik prevence, výchovný poradce, speciální pedagog. Jako speciální pedagog a školní psycholog na škole, to je skvělá věc prostě. Nám pomůže hodně.“ „Za druhý si myslím, že by měli mít i takovou jakoby, $v$ té škole by měla panovat nějaká určitá dobrá atmosféra, aby měli pocit, že v tom nejsou sami.“ Tato podpora se ukazuje například v roli asistenta, o kterého je ze strany všech vyučujících čím dál větší zájem. Učitel se pak může věnovat zbytku třídy, protože speciální péče o žáka poruchami chování či s problémovým chováním je zajištěna právě asistentem.

\section{Cílené intervence (diagnostika klimatu, preventivní programy)}

Školní metodičky prevence uváděly, že ve třídách využívají různé sociometrické metody (např́klad Sociometrický ratingový dotazník SORAD), na jejichž základě pak pedagožky volí různé postupy a formy následné práce se třídou. Dále jsou školami čím dál častěji pořádány různé adaptační kurzy, které taktéž přispívají k prevenci problémového chování na škole.

V neposlední řadě je nutné říci, že všechny školy, na kterých respondentky působí, se intenzivně věnují prevenci. Mají kontrakt s neziskovou organizací, která jim několikrát za rok poskytuje programy dlouhodobé primární prevence rizikového chování. Tyto programy jsou bezpochyby jeden $\mathrm{z}$ protektivních faktorů problémového chování žáků. 
Péče o pedagogy (psychohygiena, supervize)

Respondentky uvedly, že jim pomáhají relaxační cvičení (např́klad jóga). Dále pak rodina, na kterou se mohou spolehnout, podpora ze strany vedení nebo také různá školení týkající se syndromu vyhoření. Jedna $\mathrm{z}$ vyučujících uvedla, že je zároveň zástupkyní ředitelky a pomáhá jí tak snížená míra vyučovací povinnosti, tudíž se samotnými žáky netráví tolik času. Jedním z preventivních faktorů je taktéž supervize.

\section{Diskuze a hodnocení výsledků}

První výzkumná otázka zněla: „Kdo je, dle školních metodiček prevence, problémový žák a jak se projevuje?" Analýzy získaných dat ukázala, že se jedná o žáka, který nějakým způsobem vybočuje $\mathrm{z}$ kolektivu a chová se nestandardně. Respondentky zmiňovaly především sabotování výuky, nezájem o ni a časté vyrušování. Výsledky našeho výzkumu se shodují s výsledky výzkumu, se kterým přišli Auger a Boucharlat (2005), kde pedagogové jako jedno $\mathrm{z}$ kritérií stanovení žáka jako problémového uváděli výrazné narušování kázně ve třídě, agresivitu s tendencí napadat druhé či odmítavý postoj ke všemu. Wragg (1984) podotknul, že vyhýbání se zadané práci, mluvení bez dovolení, hluk ve tř̌idě či odbíhání z lavice je velmi obvyklé problémové chování a objevuje se častěji než například urážení pedagogů nebo ničení věcí. Taktéž mezinárodní výzkum Čiliakové, Douškové a Ivanové (2006) ukázal, že současným problémem na školách je především disciplína žáků. V našem výzkumu jako problémové žáky označily dotazované pedagožky žáky, kteří často chodí za školu a mají mnoho zameškaných hodin. Ve vztahu k učitelům je to potom drzost na vyučující a jejich nerespekt. Ve vztahu ke svým vrstevníkům spíše vzájemné napadání, agresivita a vysmívání se. Velký vliv na chování žáků ve třídě má také sám pedagog, který vytváří podmínky pro sociální chování žáků, čímž zabezpečují hladký průběh sociálních interakcí (Vacínová, 1994). Školní metodičky prevence se v našem výzkumu taktéž shodovaly, že mezi protektivní faktory, které pozitivně působí na vztah učitele a žáků patří dobré vedení třídy pedagogem a pravidelná realizace třídnických hodin, které by měly být zaměřeny na budování a posilování vztahů mezi žáky navzájem i žáky a pedagogem. Chování, které je ve společnosti typicky označované jako problémové, jako je například experimenty s alkoholem či cigaretami, předčasné zahájení sexuálního života některé respondentky naopak za problémové neoznačily, nebot̉ dle nich určitým způsobem patří $k$ věku. Vacínová (1994) taktéž uvedla, že pedagogové se při posuzování zvláštností u žáků zaměřují spíše na odlišnosti, které se týkají přímo učení. Chování žáka tedy posuzují až ve chvíli, kdy nějakým zpo̊sobem ovlivňuje chod výuky, jak negativně, tak pozitivně.

Druhá výzkumná otázka se věnovala tomu: „Co školní metodičky prevence vnimají jako největši problémovost?" Dle našeho výzkumu se jedná především o vzájemné ubližování si mezi žáky, nerespekt $\mathrm{k}$ dospělým a jejich nemotivovanost. Zároveň se na problémovém chování podílí celkem tři různé faktory. Jedná se o negativní působení v rodině - rodiče se o děti nestarají, nejsou na ně dostatečně přísní nebo se například rozvádějí. Rodiče, kteří nejsou ochotni se školou spolupracovat a svým dětem například omlouvají či kryjí záškoláctví či tací, kteří celkově problémy popírají nebo vinu svalují výhradně na školu. I tyto 
výsledky se shodují s výsledky výzkumu Augera a Boucharlata (2005), kde pedagogové jako jeden ze zdrojů problémového chování označili negativní rodinnou či sociální situaci. Mezi problémy, které často souvisí s negativním rodinným působení jsou právě například neomluvené absence, pozdní příchody do školy, náhlé výbuchy hněvu nebo neoblíbenost mezi ostatními spolužáky (Fontana, 2003). Samozřejmě je nutné zdůraznit, že výsledky našeho výzkumu se opírají pouze o názory dotazovaných pedagogů. Nedokážeme posoudit, do jaké míry s rodiči přicházejí do styku a na kolik jsou schopni posoudit rodinnou situaci žáků. Druhým faktorem, který má podíl na problémovém chování, je potom škola. Žákům neprospívá časté střídání tř̌ídních učitelů ani bagatelizace různého problémového chování ze strany pedagogů. Třetím faktorem je poté vstup žáků do období puberty, které odpovídá období sedmé tř̌́dy, kde se problémové chování u žáků mnohdy ještě více prohlubuje. Žáci si v tomto období budují vlastní identitu a potýkají se s osobnostní krizí, s kterou se pojí jak konflikty s rodiči, tak obecně všemi autoritami (Vašutová, 2005). Čapek (2008) jako př́činy nekázně taktéž označuje nedostatky ve výchovném působení rodičů i nevhodně vedené vyučování, kdy vyučující nedokáže žáky zaktivizovat a motivovat k výuce.

Třetí výzkumná otázka zněla: „S jakým problémovým chováním se školní metodičky prevence setkávají nejčastěji?" $Z$ analýzy dat vyplynulo, že se jedná o záškoláctví omlouvané rodiči, zapomínání a nerespekt $\mathrm{k}$ vyučujícím, který spočívá ve vyrušování při hodinách. $\mathrm{V}$ rámci vztahu se spolužáky pak vulgarita a vzájemné napadání se například na sociálních sítích. Co se týká rozdílů mezi poruchami chování a problémovým chováním, je dle respondentek nutné brát ohled především na diagnózu porucha chování. S tou se dle dotazovaných žák narodí a nelze s tím nic udělat. Takové chování spíše omlouvaly a odpovědnost viděly spíše na straně rodičů. Častěji se pak také mají tendence obracet na další instituce, které by jim mohly pomoci. Vojtová (2004) uvádí, že žák s poruchou chování oproti žákovi s problémovým chování necítí vinu $\mathrm{k}$ důsledkům svého jednání, normy porušuje dlouhodobě, jeho problémy se prohlubují a je nutné mu poskytnout speciální péči. Oproti tomu žák s problémovým chováním o svých problémech ví a chtěl by je odstranit, protože se mu nálepka problémového žáka nelíbí. Jeho chování má spíše krátkodobý charakter a $\mathrm{k}$ nápravu mu stačí pouze určitá pedagogická opatření v rámci školy. $Z$ analýzy dat je možné vidět, že školní metodičky prevence tyto rozdíly nevnímají. Žádná $\mathrm{z}$ respondentek se nedomnívá, že by žákovi nálepka problémového vadila, naopak uváděly, že takoví žáci nejsou motivovaní k žádné změně a je jim všechno jedno. Dále uváděly, že se z jejich zkušeností jedná o problémy dlouhodobé, což je opět v rozporu s uvedenou literaturou. Shodují se však v tom, že v případě poruch chování žák potřebuje speciální péči, na kterou v rámci prostředí školy samy nestačí.

Poslední stanovená výzkumná otázka se věnovala tomu: „Jakým způsobem ovlivňuje prritomnost problémového žáka ve tř́dě výuku?" $\mathrm{Z}$ analýzy dat jasně vyplynulo, že jeho přítomnost zásadně ovlivňuje zbytek třídy. Jelikož žák s problémovým chováním často narušuje výuku, žáci pak upírají svou pozornost $\mathrm{k}$ němu a nesoustředí se na probíranou látku. Výzkum také ukázal, že problémové chování ruší ale především samotné pedagogy a klade to na ně větší nároky při udržení pozornosti celé třídy. Přijetí problémového žáka 
zbytkem třídy záleží pak na jeho osobnosti. Pokud se jedná o silnou osobnost, ovlivní normu celé třídy tak, že v ní nikdo nechce vybočovat, aby se jim problémový žák nezačal například vysmívat. Ve chvíli, kdy je ve třídě více problémových žáků, kteří se navzájem ještě podporují v nevhodných způsobech chování, dochází k posunutí norem ve třídě a to tak, že kolektiv nevhodné projevy akceptuje či je dokonce oceňuje a považuje za běžné. Tato situace je pro pedagogy velice náročná a nemají velkou šanci uspět, co se týká změny chování (Mertin, Krejčová a kol., 2013)

\section{Limity}

Mezi limity výzkumu patři především malé množství respondentů. Naší snahou bylo se školními metodičkami prevence vést rozhovory spíše do hloubky a detailně tak zmapovat jejich názory a zkušenosti. Právě $z$ tohoto důvodu jsme do kvalitativně orientovaného výzkumu zvolili raději menší množství respondentů. Studie by však mohla být přínosná jako podklad pro větší a mnohem rozsáhlejší výzkum, který by poznatky pedagogů v oblasti problémového chování žáků na základní škole ještě více rozšiřoval.

\section{Závěr}

Výzkum vznikl jako součást diplomové práce (Sodomková, 2018) a v kontextu výzkumu vyhoření u učitelů ZŠ („Učitelské vyhoření - institucionální, vztahové a intrapsychické faktory“) podpořeného GAČR (GA16-21302S), na katedře psychologie Pedagogické fakulty UK v Praze (Smetáčková, Viktorová, Pavlas Martanová, Štech, \& Ptáček, 2019). Cílem výzkumu bylo detailně zmapovat oblast problémového chování a problémového žáka tak, jak ho vnímají školní metodici prevence, a to především ze svých vlastních zkušeností. Studie tak dokáže poskytnout náhled na vnímání problémového žáka ze strany pedagogů - školních metodiků prevence. Vnímají ho jako někoho, kdo z kolektivu vybočuje svým chováním a je jiný než ostatní žáci. Mezi nejčastější problémové chování, které ve své praxi řeší se řadí především vzájemné napadání mezi žáky, zapomínání, záškoláctví a nerespekt ke svým spolužákům i pedagogům, který se projevuje narušováním výuky. $\mathrm{Na}$ vzniku takového chování může mít podíl rodina, škola i vstup do období puberty. Výzkum také ukázal, že přítomnost takového žáka má vliv jak na ostatní spolužáky, tak především na samotného pedagoga.

\section{Grantová podpora}

„Učitelské vyhoření - institucionální, vztahové a intrapsychické faktory" podpořeného Grantovou agenturou ČR (GA16-21302S), Katedra psychologie Pedagogické fakulty UK v Praze.

\section{Reference}

Auger, M. T., \& Boucharlat, Ch. (2005). Učitel a problémový žák. Praha: Portál. Bělík, V., Hoferková, S., Kraus, B. a kol. (2017). Slovník sociální patologie. Praha: Grada. Boyatzis, R. E. (1998). Transforming Qualitative Information. Thousand Oaks: SAGE. 
Čapek, R. (2008). Odměny a tresty ve školní praxi. Praha: Grada.

Cole, T., Visser, J., \& Upton, G. (1998). Effective schooling for pupils with emotional and behavioural diffilcuties. London: David Fulton Publishers.

Čáp, D., \& Dosoudil, P. (2013) Záškoláctví. In V. Mertin \& L. Krejčová (eds.), Problémy s chováním ve škole - jak na ně: Individuálni výchovný plán (s. 149-151). Praha: Wolters Kluwer.

Čiliaková, R., Douškova, A., \& Ivanova, I. (2016). Classroom discipline problems from the teacher point of view. 3rd International Multidisciplinary Scientific Coference on Social Sciences and Arts SGEM 2016, 1 (3), 109-119. Získáno z: https://sgemworld.at/ssgemlib/spip.php?article2471

Fontana, D. (2003). Psychologie ve školni praxi: Př́ručka pro učitele. Praha: Portál.

Knotová D. et al. (2014). Školní poradenství. Praha: Grada.

Mertin, V., \& Krejčová, L. et al. (2013). Problémy s chováním ve škole - jak na ně: individuální výchovný plán. Praha: Wolters Kluwer Česká republika.

Nielsen Sobotková, V. (2014). Rizikové a antisociální chování v adolescenci. Praha: Grada.

Rabušicová, M., \& Pol, M. (1996). Vztahy školy a rodiny dnes: hledání cest k partnerství (1. část). Časopis Pedagogika, 1, 49-61.

Smetáčková, I., Viktorová, I., Štech, S., Pavlas Martanová, V., Páchová, A., \& Ptáček, R. (2019). Vztah syndromu vyhoření, copingových strategií a self-efficacy mezi vyučujícími na českých základních školách. Československá psychologie, 63(4), 386-401.

Sodomková, N. (2018). Problematický žák z pohledu učitele. Praha: Pedagogická fakulta UK.

Strauss, A. L., \& Corbin, J. (1994). Grounded theory methodology: An overwiev. In N. K. Denzin, \& Y. S. Lincoln (Eds.), Handbook of qualitative research (s. 273-285). Thousand Oaks, CA, US: Sage Publications.

Strauss, A. L., \& Corbin, J. (1999). Základy kvalitativního výzkumu: postupy a techniky metody zakotvené teorie. Brno: Sdružení podané ruce.

Vacínová, M. (1994). Role učitelů ve vytváření vhodného stimulujícího prostředí. In M. Langová \& M. Vacínová, Jak se to chováš? (s. 41-44). Praha: EMPATIE.

Vágnerová, M. (2001). Psychologie problémového ditěte školního věku. Praha: Karolinum.

Vašutová, J. (2002). Být učitelem. Praha: Univerzita Karlova v Praze, Pedagogická fakulta.

Vašutová, M. (2005). Pedagogické a psychologické problémy v dětství a dospívání. Ostrava: Ostravská univerzita v Ostravě, Filozofická fakulta.

Veselá, J. (2006). Vliv pedagogických dovedností tř́dního učitele na klima tř́dy. In 2. konference Škola a zdraví pro 21. století. Brno: Pedagogická fakulta.

Vojtová, V. (2004). Edukace žáků s poruchami chování. In M. Vítková (ed.), Integrativní školní (speciální) pedagogika: Základy, teorie, praxe (s. 191-203). Brno: MSD.

Wragg, E. C. (1984). Classroom teaching skills: the research findings of the Teacher Education Project. New York: Nichols Publications.

\section{Legislativní dokumenty}

Vyhláška č. 72/2005 Sb. Vyhláška o poskytováni poradenských služeb ve školách a školských zařizeních. Ve zněni pozdějších novelizací.

Korespondenční autorka: Nikola Petrek, Katedra Psychologie, Pedagogická fakulta,

Univerzita Karlova, Myslíkova 7, 11000 Praha 1, Česká republika.

Email: nikola.petrek.np@gmail.com

Petrek, N., \& Pavlas Martanová, V. (2020). Problémový žák a problémové chování z pohledu školních metodiček prevence. Psychologie a její kontexty, 77(1), 55-68. https://doi.org/10.15452/PsyX.2020.11.0004 